\title{
Psychrobacter aquimaris sp. nov. and Psychrobacter namhaensis sp. nov., isolated from sea water of the South Sea in Korea
}

Correspondence Jung-Hoon Yoon jhyoon@kribb.re.kr

\author{
Jung-Hoon Yoon, ${ }^{1}$ Choong-Hwan Lee, ${ }^{1}$ Soo-Hwan $Y^{2}{ }^{2}$ \\ and Tae-Kwang $\mathrm{Oh}^{1}$
${ }^{1}$ Korea Research Institute of Bioscience and Biotechnology (KRIBB), PO Box 115, Yusong, Taejon, Korea
${ }^{2}$ The Center for Traditional Microorganism Resources, Keimyung University, Shindang-Dong, Dalseo-gu, Daegu, Korea

\begin{abstract}
Two Gram-negative, non-motile, non-spore-forming, slightly halophilic bacterial strains, SW-210 ${ }^{\top}$ and SW $-242^{\top}$, were isolated from sea water of the South Sea in Korea, and were characterized taxonomically by means of a polyphasic approach. The two isolates grew optimally at $25-30^{\circ} \mathrm{C}$ and in the presence of $2-3 \%(\mathrm{w} / \mathrm{v}) \mathrm{NaCl}$. Strains SW $-210^{\top}$ and SW $-242^{\top}$ contained Q-8 as the predominant respiratory lipoquinone and $\mathrm{C}_{18: 1} \omega 9 \mathrm{c}$ as the major fatty acid. The DNA G $+C$ contents of strains $S W-210^{\top}$ and $S W-242^{\top}$ were $43 \cdot 2$ and $45 \cdot 3$ mol\%, respectively. The 16S rRNA gene sequences of strains $S W-210^{\top}$ and $S W-242^{\top}$ were $98 \cdot 9 \%$ similar, and the mean DNA-DNA relatedness value between them was $24 \%$. Phylogenetic analysis based on 16S rRNA gene sequences showed that strains SW-210 ${ }^{\top}$ and $S W-242^{\top}$ form distinct phylogenetic lineages within the radiation of the cluster comprising Psychrobacter species, having 16S rRNA gene sequence similarity levels of $95 \cdot 9-99 \cdot 2 \%$ with respect to the type strains of Psychrobacter species. The levels of DNA-DNA relatedness between the two isolates and the type strains of 15 phylogenetically related Psychrobacter species were well below $70 \%$. On the basis of phenotypic and phylogenetic data and genomic distinctiveness, strains SW-210 ${ }^{\top}$ and SW $-242^{\top}$ were classified in the genus Psychrobacter as representing two distinct novel species, for which the names Psychrobacter aquimaris sp. nov. (type strain, SW $-210^{\top}=$ KCTC $12254^{\top}=$ DSM $16329^{\top}$ ) and Psychrobacter namhaensis sp. nov. (type strain, SW $-242^{\top}=$ KCTC $12255^{\top}=\mathrm{DSM} 16330^{\top}$ ) are proposed, respectively.
\end{abstract}

The genus Psychrobacter was proposed by Juni \& Heym (1986), and, at the time of writing, the genus comprises at least 18 species with validly published names: Psychrobacter immobilis (Juni \& Heym, 1986), Psychrobacter frigidicola, Psychrobacter urativorans and Psychrobacter phenylpyruvicus (Bowman et al., 1996), Psychrobacter glacincola (Bowman et al., 1997), Psychrobacter pacificensis (Maruyama et al., 2000), Psychrobacter proteolyticus (Denner et al., 2001), Psychrobacter submarinus and Psychrobacter marincola (Romanenko et al., 2002), Psychrobacter faecalis (Kämpfer et al., 2002), Psychrobacter pulmonis (Vela et al., 2003), Psychrobacter jeotgali (Yoon et al., 2003), Psychrobacter luti and Psychrobacter fozii (Bozal et al., 2003), Psychrobacter okhotskensis (Yumoto et al., 2003), Psychrobacter maritimus

Published online ahead of print on 3 December 2004 as DOI 10.1099/ ijs.0.63464-0.

The GenBank/EMBL/DDBJ accession numbers for the 16S rRNA gene sequences of strains SW-210 ${ }^{\top}$ and $S W-242^{\top}$ are AY722804 and AY722805, respectively. and Psychrobacter arenosus (Romanenko et al., 2004) and Psychrobacter alimentarius (Yoon et al., 2005). In this study, we report on the detailed taxonomic characterization of two Psychrobacter-like bacterial strains, SW-210 ${ }^{\mathrm{T}}$ and SW$242^{\mathrm{T}}$, which were isolated from sea water of the South Sea in Korea.

Sea water collected from the South Sea in Korea was used as source for the isolation of bacterial strains. Strains SW$210^{\mathrm{T}}$ and SW- $242^{\mathrm{T}}$ were isolated by using the usual dilution plating technique on marine agar 2216 (MA; Difco) at $30{ }^{\circ} \mathrm{C}$. The type strains of 15 Psychrobacter species were used as reference strains for DNA-DNA hybridization. $P$. faecalis DSM $14664^{\mathrm{T}}, P$. frigidicola DSM $12411^{\mathrm{T}}$, P. glacincola DSM $12194^{\mathrm{T}}, P$. immobilis DSM $7229^{\mathrm{T}}, P$. marincola DSM $14160^{\mathrm{T}}, P$. proteolyticus DSM $13887^{\mathrm{T}}, P$. submarinus DSM $14161^{\mathrm{T}}$ and $P$. urativorans DSM $14009^{\mathrm{T}}$ were obtained from the Deutsche Sammlung von Mikroorganismen und Zellkulturen, Braunschweig, Germany. P. okhotskensis JCM $11840^{\mathrm{T}}$ was obtained from the Japan 


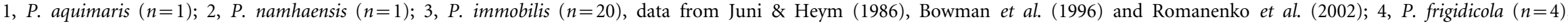

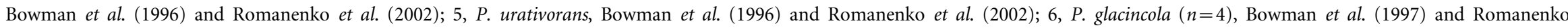

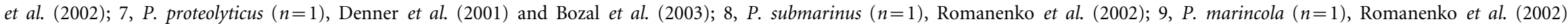

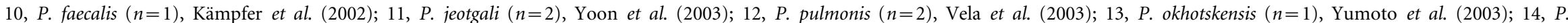

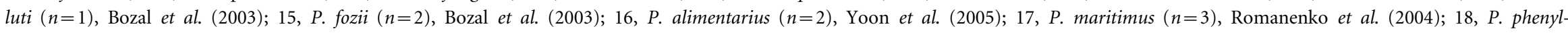

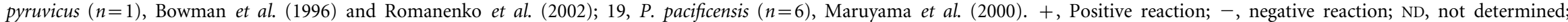

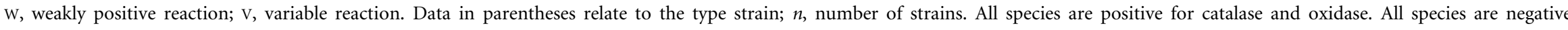

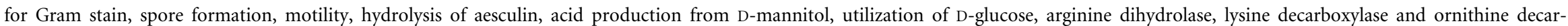
boxylase.

\begin{tabular}{|c|c|c|c|c|c|c|c|c|c|c|c|c|c|c|c|c|c|c|c|}
\hline Characteristic & 1 & 2 & 3 & 4 & 5 & 6 & 7 & 8 & 9 & 10 & 11 & 12 & 13 & 14 & 15 & 16 & 17 & 18 & 19 \\
\hline Cell morphology* & $\mathrm{C}$ or $\mathrm{SR}$ & $\mathrm{C}$ or $\mathrm{SR}$ & $\mathrm{CB}$ & C & C & $\mathrm{C}$ & $\mathrm{CB}$ & $\mathrm{O}$ & $\mathrm{C}$ & $\mathrm{R}$ & C & $\mathrm{C}$ & $\mathrm{R}$ & $\mathrm{CB}$ & $\mathrm{CB}$ & $\mathrm{C}$ & $\mathrm{O}$ & SR & $\mathrm{CB}$ \\
\hline Anaerobic growth & + & + & - & - & - & - & - & - & - & - & - & - & - & - & - & - & - & - & - \\
\hline Urease & - & - & $\mathrm{v}(+)$ & - & $\mathrm{v}(+)$ & $\mathrm{v}(-)$ & + & - & - & - & + & - & - & - & + & - & ND & + & + \\
\hline Tryptophan deaminase & - & - & $\mathrm{v}(-)$ & + & - & - & - & - & - & $\mathrm{ND}$ & - & - & ND & - & - & - & $\mathrm{ND}$ & - & - \\
\hline Nitrate reduction & - & - & $\mathrm{v}(-)$ & - & $\mathrm{v}(-)$ & $\mathrm{v}(+)$ & - & - & - & ND & + & + & + & + & - & - & + & - & - \\
\hline \multicolumn{20}{|l|}{ Hydrolysis of: } \\
\hline Casein & - & - & - & - & - & - & + & - & - & $\mathrm{ND}$ & - & ND & - & + & - & - & - & - & $\mathrm{ND}$ \\
\hline Gelatin & - & - & - & - & - & - & + & - & - & $\mathrm{ND}$ & - & - & - & - & - & - & - & - & - \\
\hline Starch & - & - & - & - & - & - & - & - & - & $\mathrm{ND}$ & - & ND & $\mathrm{ND}$ & - & - & - & - & - & $\mathrm{ND}$ \\
\hline Tween 40 & + & + & + & - & - & + & ND & + & - & $\mathrm{ND}$ & ND & ND & + & ND & ND & + & + & - & ND \\
\hline Tween 80 & + & + & + & - & - & + & w & + & + & $\mathrm{ND}$ & + & $\mathrm{ND}$ & + & + & - & + & + & + & $\mathrm{ND}$ \\
\hline Xanthine & - & - & ND & ND & ND & $\mathrm{v}$ & ND & ND & ND & ND & - & ND & ND & ND & ND & - & ND & - & ND \\
\hline \multicolumn{20}{|l|}{ Growth in: } \\
\hline $0 \%(\mathrm{w} / \mathrm{v}) \mathrm{NaCl}$ & + & + & + & + & + & + & ND & - & - & ND & + & ND & + & + & $\mathrm{v}(+)$ & + & + & + & - \\
\hline $10 \%(\mathrm{w} / \mathrm{v}) \mathrm{NaCl}$ & + & + & $\mathrm{v}(+)$ & - & - & + & + & + & + & + & + & ND & + & - & + & + & + & - & - \\
\hline $15 \%(\mathrm{w} / \mathrm{v}) \mathrm{NaCl}$ & - & - & - & - & - & - & ND & + & + & $\mathrm{ND}$ & - & ND & - & - & - & - & - & - & - \\
\hline Growth temp. (max., $\left.{ }^{\circ} \mathrm{C}\right)$ & 34 & 37 & $(<35-37)$ & $19-22$ & $25-27$ & $19-22$ & $<35$ & 35 & 35 & 36 & 36 & $<42$ & 35 & 30 & 30 & 35 & $39-40$ & $<40$ & 38 \\
\hline Optimum growth temp. $\left({ }^{\circ} \mathrm{C}\right)$ & $25-30$ & $25-30$ & (20) & $14-16$ & $18-20$ & $13-15$ & $19-25$ & $25-28$ & $25-28$ & $15-30$ & $25-30$ & ND & 25 & 15 & 15 & 30 & $25-28$ & $33-37$ & 25 \\
\hline \multicolumn{20}{|l|}{ Acid production from: } \\
\hline D-Glucose & + & + & + & - & - & - & + & - & - & - & - & - & - & - & - & + & - & - & + \\
\hline D-Xylose & + & + & + & - & - & - & ND & - & - & - & - & ND & - & - & - & + & - & - & + \\
\hline L-Arabinose & + & + & + & - & - & - & + & + & - & - & - & - & - & - & - & + & - & - & + \\
\hline D-Fructose & - & - & - & - & - & - & $\mathrm{ND}$ & + & - & ND & - & ND & - & - & - & - & - & - & ND \\
\hline L-Rhamnose & + & + & + & - & - & - & + & - & - & - & - & - & $\mathrm{ND}$ & - & - & + & - & - & ND \\
\hline D-Galactose & + & + & + & - & - & - & ND & - & - & ND & - & ND & - & - & - & + & - & - & ND \\
\hline Maltose & - & - & - & - & - & - & ND & - & - & - & - & ND & - & - & - & - & - & - & $\mathrm{ND}$ \\
\hline Lactose & + & + & $\mathrm{v}(-)$ & - & - & - & ND & - & - & - & - & ND & - & - & - & + & - & - & $\mathrm{ND}$ \\
\hline \multicolumn{20}{|l|}{ Utilization of: } \\
\hline Acetate & + & + & + & + & $\mathrm{v}(+)$ & + & + & - & - & + & + & ND & $\mathrm{ND}$ & + & $\mathrm{v}(+)$ & + & + & + & $\mathrm{v}(-)$ \\
\hline Pyruvate & + & + & + & - & + & + & ND & $\mathrm{ND}$ & $\mathrm{ND}$ & + & + & ND & + & ND & + & + & - & + & $\mathrm{ND}$ \\
\hline Citrate & - & - & $\mathrm{v}(-)$ & - & - & $\mathrm{v}$ & + & - & - & + & - & - & $\mathrm{ND}$ & + & - & + & - & + & - \\
\hline Malate & + & + & + & + & $\mathrm{v}(+)$ & - & - & - & - & + & $\mathrm{v}(-)$ & - & + & + & + & + & $\mathrm{v}(-)$ & + & + \\
\hline Succinate & + & + & + & - & - & - & $\mathrm{ND}$ & $\mathrm{ND}$ & $\mathrm{ND}$ & $\mathrm{ND}$ & + & $\mathrm{ND}$ & $\mathrm{ND}$ & + & + & + & - & - & $\mathrm{ND}$ \\
\hline
\end{tabular}




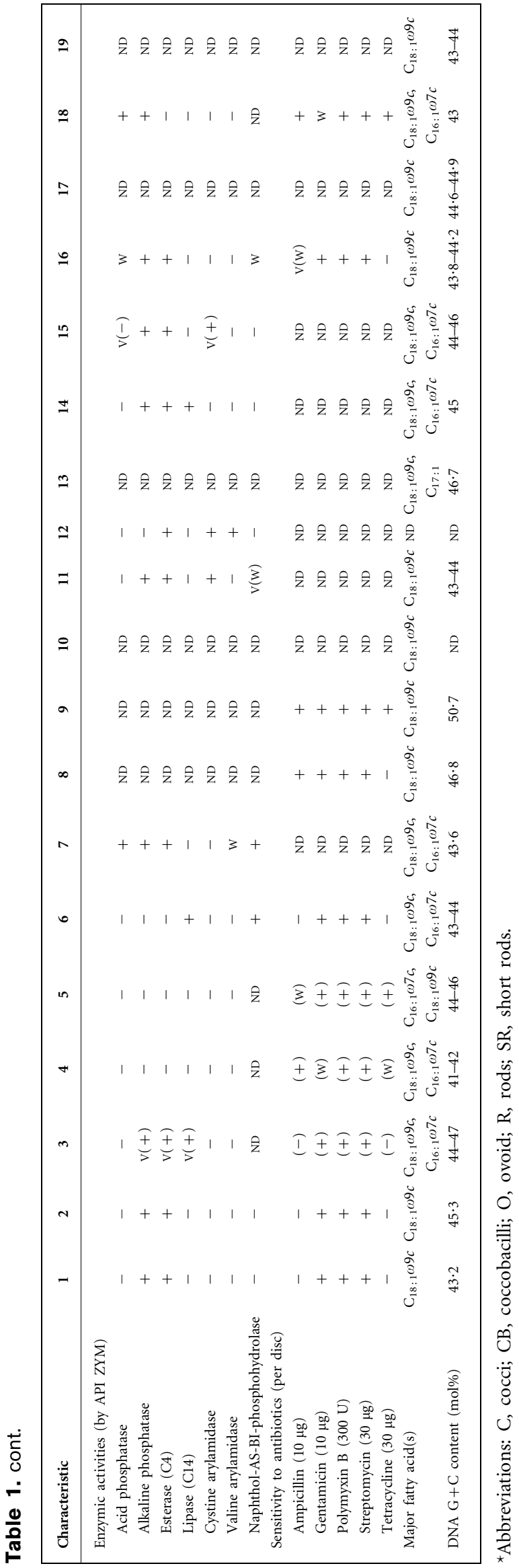

Collection of Microorganisms, Saitama, Japan. P. fozii CECT $5889^{\mathrm{T}}$, P. luti CECT $5885^{\mathrm{T}}$ and $P$. pulmonis CECT $5989^{\mathrm{T}}$ were obtained from the Colección Española de Cultivos Tipo, Valencia, Spain. P. jeotgali KCCM $41559^{\mathrm{T}}$ and $P$. alimentarius $\mathrm{JG}-100^{\mathrm{T}}$ were obtained and described in the studies of Yoon et al. $(2003,2005)$. P. maritimus KMM $3646^{\mathrm{T}}$ was obtained from Dr O. I. Nedashkovskaya and Dr L. A. Romanenko, Pacific Institute of Bioorganic Chemistry, Vladivostok, Russia. Cell morphology was examined by light microscopy (E600 microscope; Nikon) and transmission electron microscopy (CM-20 apparatus; Philips). Transmission electron microscopy was also used to determine if flagella were present in cells from exponentially growing cultures. The Gram reaction was determined by using the bioMerieux Gram stain kit according to the manufacturer's instructions. The $\mathrm{pH}$ range for growth was determined in marine broth 2216 (MB; Difco) that was adjusted to various $\mathrm{pH}$ values $(\mathrm{pH} 4 \cdot 5-9 \cdot 5$ at intervals of $0.5 \mathrm{pH}$ units). Growth in the absence of $\mathrm{NaCl}$ was investigated in trypticase/soy broth (Difco) lacking $\mathrm{NaCl}$. Growth at various $\mathrm{NaCl}$ concentrations was investigated in $\mathrm{MB}$ or trypticase/soy broth. Growth at various temperatures $\left(4-45^{\circ} \mathrm{C}\right)$ was measured on MA. Growth under anaerobic conditions was determined after incubation in an anaerobic chamber on MA and on MA supplemented with nitrate, both of which had been prepared anaerobically using nitrogen. Catalase and oxidase activities and hydrolysis of casein, starch and Tweens 20, 40, 60 and 80 were determined as described by Cowan \& Steel (1965). Hydrolysis of aesculin and nitrate reduction were determined as described previously (Lanyi, 1987). Hydrolysis of gelatin and urea was determined as described by Lanyi (1987), with the modification that artificial sea water was used instead of distilled water. The artificial sea water contained (per litre of distilled water) $23.6 \mathrm{~g} \mathrm{NaCl}, 0.64 \mathrm{~g}$ $\mathrm{KCl}, 4.53 \mathrm{~g} \mathrm{MgCl}_{2} \cdot 6 \mathrm{H}_{2} \mathrm{O}$, $5.94 \mathrm{~g} \mathrm{MgSO}_{4} \cdot 7 \mathrm{H}_{2} \mathrm{O}$ and $1.3 \mathrm{~g}$ $\mathrm{CaCl}_{2} \cdot 2 \mathrm{H}_{2} \mathrm{O}$ (Bruns et al., 2001). Hydrolysis of hypoxanthine, tyrosine and xanthine was investigated on MA with the substrate concentrations described previously (Cowan \& Steel, 1965). $\mathrm{H}_{2} \mathrm{~S}$ production was tested as described previously (Bruns et al., 2001). Acid production from carbohydrates was determined as described by Leifson (1963). Enzyme activity was determined by using the API ZYM system (bioMérieux). Utilization of substrates as sole carbon and energy sources was tested according to the method of Baumann \& Baumann (1981) using supplementation with $2 \%(\mathrm{v} / \mathrm{v})$ Hutner's mineral base (CohenBazire et al., 1957) and $1 \%(\mathrm{v} / \mathrm{v})$ vitamin solution (Staley, 1968). Requirements for yeast extract and vitamins for growth were investigated in liquid medium (Yurkov et al., 1994), omitting yeast extract and vitamin $B_{12}$ but supplementing with $0 \cdot 1 \%(\mathrm{w} / \mathrm{v})$ acetate as the sole carbon and energy source. Yeast extract and vitamins were added to the medium at the following concentrations $\left(1^{-1}\right)$ : yeast extract, $0.005 \mathrm{~g}$; $p$-aminobenzoic acid, $1 \mathrm{mg}$; biotin, $10 \mu \mathrm{g}$; thiamine hydrochloride, $1 \mathrm{mg}$; and vitamin $\mathrm{B}_{12}, 1 \mathrm{mg}$. Susceptibility to antibiotics was detected on MA plates using antibiotic discs with the following concentrations: 
polymyxin $\mathrm{B}, 100 \mathrm{U}$; streptomycin, $50 \mu \mathrm{g}$; penicillin $\mathrm{G}, 20 \mathrm{U}$; chloramphenicol, $100 \mu \mathrm{g}$; ampicillin, $10 \mu \mathrm{g}$; cephalothin, $30 \mu \mathrm{g}$; gentamicin, $30 \mu \mathrm{g}$; novobiocin, $5 \mu \mathrm{g}$; erythromycin, $15 \mu \mathrm{g}$; and tetracycline, $30 \mu \mathrm{g}$. Other physiological tests were performed with the API $20 \mathrm{E}$ system (bioMérieux).

Cell biomass for respiratory lipoquinone analysis and for DNA extraction was obtained from cultivation in $\mathrm{MB}$ at $30^{\circ} \mathrm{C}$. Respiratory lipoquinones were analysed as described by Komagata \& Suzuki (1987), using reversed-phase HPLC. Chromosomal DNA was isolated and purified according to the method described previously (Yoon et al., 1996), with the exception that ribonuclease T1 was used together with ribonuclease A to minimize the contamination of RNA. For fatty acid methyl ester analysis, cell mass of strains SW $-210^{\mathrm{T}}$ and $\mathrm{SW}-242^{\mathrm{T}}$ was harvested from agar plates after incubation for 3 days at $30^{\circ} \mathrm{C}$ on MA. The fatty acid methyl esters were extracted and prepared according to the standard protocol of the MIDI/Hewlett Packard Microbial Identification System (Sasser, 1990). The DNA $\mathrm{G}+\mathrm{C}$ content was determined by the method of Tamaoka \& Komagata (1984), with the modification that DNA was hydrolysed and the resultant nucleotides were analysed by reversed-phase HPLC. 16S rRNA genes were amplified by the PCR method, using two universal primers as described previously (Yoon et al., 1998). Sequencing of the amplified 16S rRNA genes and phylogenetic analysis were performed as described by Yoon et al. (2003). DNA-DNA hybridization was performed fluorometrically according to the method of Ezaki et al. (1989), using photobiotinlabelled DNA probes and microdilution wells. Hybridization was performed with five replications for each sample. The highest and lowest values obtained in each sample were excluded and the remaining three values were used to calculate similarity values. The DNA relatedness values quoted are the means of the three values.

Cells of strains SW-210 ${ }^{\mathrm{T}}$ and $\mathrm{SW}-242^{\mathrm{T}}$ were cocci or short rods on MA. Strains SW $-210^{\mathrm{T}}$ and SW $-242^{\mathrm{T}}$ did not require yeast extract or vitamins for growth in minimal salts medium (Yurkov et al., 1994). However, both strains grew better when yeast extract was added to the medium. Benzoate was utilized by strain $\mathrm{SW}-242^{\mathrm{T}}$ but not by strain $\mathrm{SW}-210^{\mathrm{T}}$. Strain $\mathrm{SW}-210^{\mathrm{T}}$ was sensitive to penicillin $\mathrm{G}$ but strain SW- $242^{\mathrm{T}}$ was not. Other morphological, cultural, physiological and biochemical characteristics of strains SW $-210^{\mathrm{T}}$ and SW $-242^{\mathrm{T}}$ are given in the species description (see below) and are shown in Table 1 together with those of some Psychrobacter species. The predominant respiratory lipoquinone found in strains SW- $210^{\mathrm{T}}$ and $\mathrm{SW}-242^{\mathrm{T}}$ was Q-8, at a peak area ratio of approximately $84-86 \%$. The major components of the fatty acids detected in strains SW $-210^{\mathrm{T}}$ and $\mathrm{SW}-242^{\mathrm{T}}$ were $\mathrm{C}_{18: 1} \omega 9 \mathrm{c}$ and $\mathrm{C}_{17: 1} \omega 8 c$ (Table 2). These fatty acid profiles were similar to those determined previously for other Psychrobacter species, although there were differences in the proportions of some fatty acids, perhaps because of differences in cultivation
Table 2. Cellular fatty acid composition (\%) of strain SW$210^{\top}$ and strain $\mathrm{SW}-242^{\top}$ on MA

Fatty acids representing less than $0.5 \%$ in each of the two strains were omitted. -, Not detected.

\begin{tabular}{|c|c|c|}
\hline Fatty $\operatorname{acid}^{\star}$ & $S W-210^{T}$ & $S W-242^{\mathrm{T}}$ \\
\hline \multicolumn{3}{|c|}{ Straight-chain fatty acids } \\
\hline $\mathrm{C}_{9: 0}$ & $1 \cdot 0$ & $1 \cdot 2$ \\
\hline $\mathrm{C}_{10: 0}$ & $3 \cdot 1$ & $2 \cdot 9$ \\
\hline $\mathrm{C}_{11: 0}$ & $0 \cdot 4$ & $0 \cdot 7$ \\
\hline $\mathrm{C}_{16: 0}$ & $1 \cdot 3$ & $0 \cdot 8$ \\
\hline $\mathrm{C}_{18: 0}$ & $1 \cdot 8$ & $0 \cdot 9$ \\
\hline \multicolumn{3}{|c|}{ Branched fatty acid } \\
\hline iso- $\mathrm{C}_{17: 0}$ & $1 \cdot 1$ & $0 \cdot 9$ \\
\hline \multicolumn{3}{|c|}{ Unsaturated fatty acids } \\
\hline $\mathrm{C}_{17: 1} \omega 8 c$ & $12 \cdot 6$ & $18 \cdot 1$ \\
\hline $\mathrm{C}_{18: 1} \omega 7 c$ & $2 \cdot 0$ & $1 \cdot 5$ \\
\hline $\mathrm{C}_{18: 1} \omega 9 c$ & $64 \cdot 9$ & $58 \cdot 7$ \\
\hline \multicolumn{3}{|c|}{ Hydroxy fatty acids } \\
\hline $\mathrm{C}_{12: 0} 3-\mathrm{OH}$ & $2 \cdot 6$ & $2 \cdot 9$ \\
\hline $\mathrm{C}_{16: 0} 2-\mathrm{OH}$ & - & $0 \cdot 9$ \\
\hline \multicolumn{3}{|c|}{ Summed features ${ }^{*}$} \\
\hline 1 & $0 \cdot 9$ & $1 \cdot 1$ \\
\hline 2 & $0 \cdot 9$ & $1 \cdot 0$ \\
\hline 3 & $5 \cdot 7$ & $6 \cdot 5$ \\
\hline 6 & $0 \cdot 8$ & $0 \cdot 8$ \\
\hline
\end{tabular}

${ }^{\star}$ Summed features represent groups of two or three fatty acids that could not be separated by GLC with the MIDI system. Summed feature 1 contained one or more of $\mathrm{C}_{13: 0} 3-\mathrm{OH}$ and/or iso- $\mathrm{C}_{15: 1}$. Summed feature 2 contained one or more of iso- $\mathrm{C}_{16: 1} \mathrm{I}$ and/or $\mathrm{C}_{14: 0}$ 3-OH. Summed feature 3 contained one or more of $\mathrm{C}_{16: 1} \omega 7 c$ and/or iso- $\mathrm{C}_{15: 0}$ 2-OH. Summed feature 6 contained one or more of $\mathrm{C}_{19: 1} \omega 9 c$ and/or $\mathrm{C}_{19: 1} \omega 11 c$.

conditions, e.g. cultivation media (Maruyama et al., 2000; Romanenko et al., 2002, 2004; Bozal et al., 2003; Yumoto et al., 2003; Yoon et al., 2005). The DNA G + C contents of strains SW-210 ${ }^{\mathrm{T}}$ and $\mathrm{SW}-242^{\mathrm{T}}$ were $43 \cdot 2$ and $45 \cdot 3 \mathrm{~mol} \%$, respectively.

The almost-complete 16S rRNA gene sequences of strains SW- $210^{\mathrm{T}}$ and $\mathrm{SW}-242^{\mathrm{T}}$ determined in this study each comprised $1494 \mathrm{nt}$, representing approximately $96 \%$ of the Escherichia coli 16S rRNA sequence. There were $17 \mathrm{bp}$ sequence differences (i.e. $98.9 \%$ identity) between the $16 \mathrm{~S}$ rRNA gene sequence of strain $\mathrm{SW}-210^{\mathrm{T}}$ and that of strain $\mathrm{SW}-242^{\mathrm{T}}$. Comparative analysis revealed that strains SW$210^{\mathrm{T}}$ and $\mathrm{SW}-242^{\mathrm{T}}$ had the highest $16 \mathrm{~S}$ rRNA gene sequence similarities to members of the genus Psychrobacter. Phylogenetic trees based on 16S rRNA gene sequences showed that the two isolates fall within the evolutionary radiation encompassed by the genus Psychrobacter (Fig. 1). Strains SW-210 ${ }^{\mathrm{T}}$ and SW-242 ${ }^{\mathrm{T}}$ exhibited $16 \mathrm{~S}$ rRNA gene sequence similarity levels of $96 \cdot 0-99 \cdot 2 \%$ and $95 \cdot 9-98 \cdot 9 \%$, respectively, with respect to the type strains of Psychrobacter 


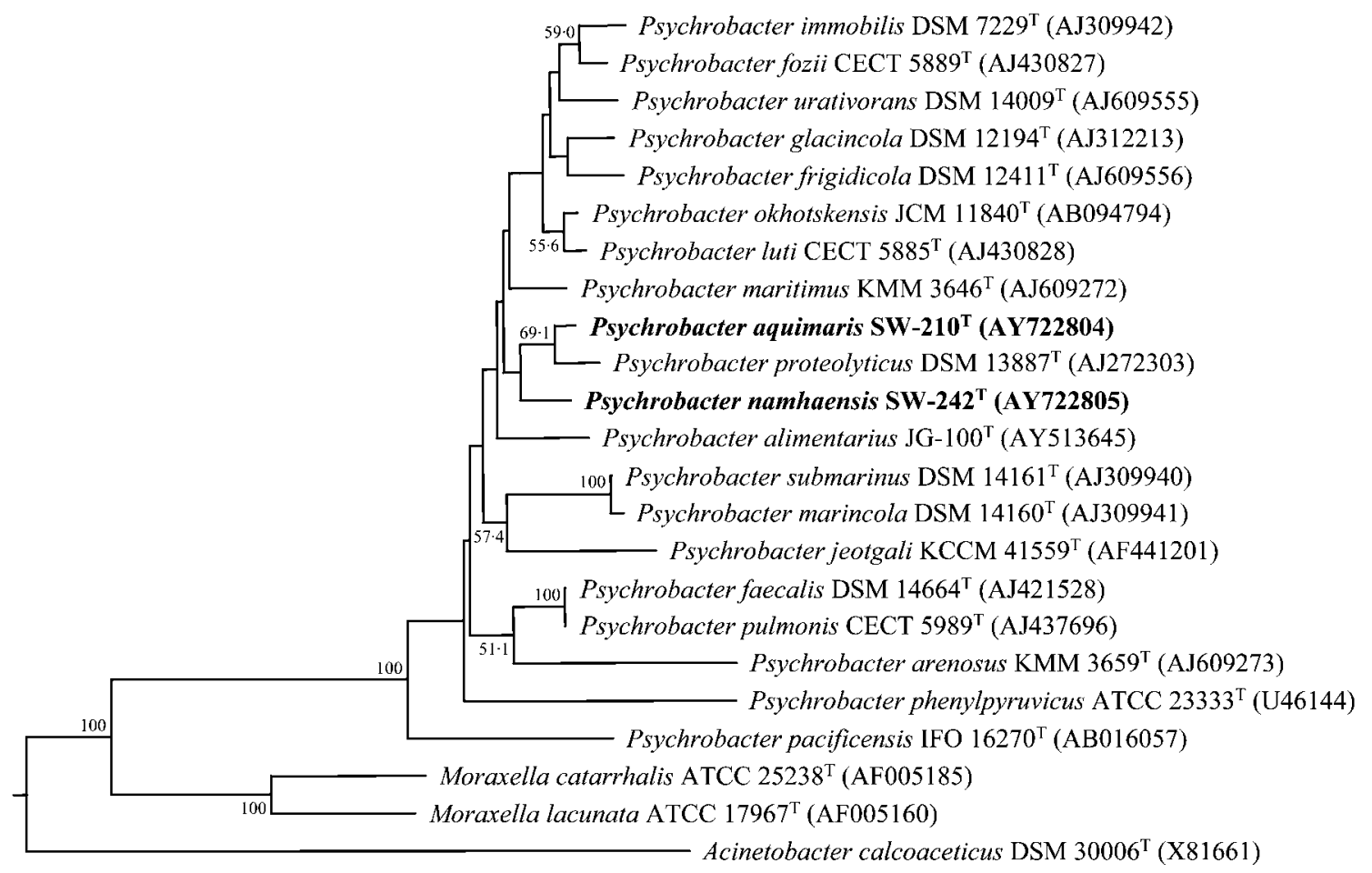

$0 \cdot 01$

Fig. 1. Neighbour-joining tree, based on $16 \mathrm{~S}$ rRNA gene sequences, showing the phylogenetic positions of strains SW-210 ${ }^{\top}$ and SW-242 ${ }^{\top}$ and representatives of some other related taxa. Bootstrap values (expressed as percentages of 1000 replications) greater than $50 \%$ are shown at the branch points. Pseudomonas aeruginosa DSM $50071^{\top}$ was used as the outgroup. Scale bar represents 0.01 substitution per nucleotide position.

species with validly published names. The $16 \mathrm{~S}$ rRNA gene sequence similarities of the two isolates with respect to other species included in the phylogenetic analysis were below $92.5 \%$ (Fig. 1). DNA-DNA hybridization was performed to determine the level of genetic relatedness between strain SW $-210^{\mathrm{T}}$ and strain SW $-242^{\mathrm{T}}$ and also those between each of the two strains and the type strains of some Psychrobacter species that exhibited 16S rRNA gene sequence similarity values above $97 \%$ with respect to the two novel isolates. Strains $\mathrm{SW}-210^{\mathrm{T}}$ and $\mathrm{SW}-242^{\mathrm{T}}$ exhibited a mean level of DNA-DNA relatedness of $24 \%$ when their DNAs were used individually as labelled DNA probes for cross-hybridization. Levels of DNA-DNA relatedness between two strains and the type strains of 15 Psychrobacter species were in the range $6-35 \%$.

In the neighbour-joining tree, inferred from comparison of 16S rRNA gene sequences, the cluster comprising the two isolates and Psychrobacter species was distinguishable from the genus Moraxella at a bootstrap confidence level of $100 \%$ (Fig. 1). The thermal tolerance and chemotaxonomic data (the predominant respiratory lipoquinone, the cellular fatty acid profile and the DNA $\mathrm{G}+\mathrm{C}$ content) for strains $\mathrm{SW}-210^{\mathrm{T}}$ and $\mathrm{SW}-242^{\mathrm{T}}$ are similar to those for Psychrobacter species (Bøvre, 1984; Kodjo et al., 1995, 1997;
Bowman et al., 1997; Maruyama et al., 2000; Yoon et al., 2003; Bozal et al., 2003; Yumoto et al., 2003). Strains SW $-210^{\mathrm{T}}$ and SW $-242^{\mathrm{T}}$ are similar to each other in terms of most phenotypic characteristics (Table 1). However, the two strains differ from each other phylogenetically and genetically. Strains SW $-210^{\mathrm{T}}$ and $\mathrm{SW}-242^{\mathrm{T}}$ are distinguishable from phylogenetically related Psychrobacter species by differences in physiological and biochemical characteristics (Table 1). The level of DNA relatedness, together with differential phenotypic properties and 16S rRNA gene sequence similarity data, justifies the taxonomic discrimination of strains SW-210 ${ }^{\mathrm{T}}$ and SW- $242^{\mathrm{T}}$ from all Psychrobacter species (Wayne et al., 1987; Stackebrandt \& Goebel, 1994). Therefore, on the basis of the data presented, strains $\mathrm{SW}-210^{\mathrm{T}}$ and $\mathrm{SW}-242^{\mathrm{T}}$ should be placed in the genus Psychrobacter as representing two distinct novel species, for which the names Psychrobacter aquimaris sp. nov. and Psychrobacter namhaensis sp. nov., respectively, are proposed.

\section{Description of Psychrobacter aquimaris sp. nov.}

Psychrobacter aquimaris (a.qui.ma'ris. L. n. aqua water; L. gen. n. maris of the sea; N.L. gen. n. aquimaris of the water of the sea). 
Cells are cocci or short rods $(1 \cdot 0-1 \cdot 2 \times 1 \cdot 4-2 \cdot 5 \mu \mathrm{m})$. On MA, colonies are smooth, glistening, raised, circular to slightly irregular, cream in colour and $1.5-2.5 \mathrm{~mm}$ in diameter after incubation for 3 days at $30^{\circ} \mathrm{C}$. Growth occurs at 4 and $34{ }^{\circ} \mathrm{C}$ but not at $35^{\circ} \mathrm{C}$. Optimal pH for growth is $6.5-7 \cdot 5$; growth occurs at $\mathrm{pH} 5.0$ but not at $4 \cdot 5$. Growth occurs in the presence of $0-12 \%(\mathrm{w} / \mathrm{v}) \mathrm{NaCl}$, with an optimum of $2-3 \%(\mathrm{w} / \mathrm{v})$. Yeast extract, biotin, $p$-aminobenzoic acid, thiamine hydrochloride and vitamin $B_{12}$ are not required for growth. Tyrosine is hydrolysed, but hypoxanthine is not. Indole and $\mathrm{H}_{2} \mathrm{~S}$ are not produced. In assays with the API ZYM system, lipase (C8) and leucine arylamidase are present, but trypsin, $\alpha$-chymotrypsin, $\alpha$-galactosidase, $\beta$-galactosidase, $\beta$-glucuronidase, $\alpha$-glucosidase, $\quad \beta$-glucosidase, $\quad N$-acetyl- $\beta$-glucosaminidase, $\alpha$ mannosidase and $\alpha$-fucosidase are absent. L-Arabinose, D-cellobiose, D-fructose, D-galactose, lactose, maltose, Dmannose, sucrose, D-trehalose, D-xylose, benzoate, formate and L-glutamate are not utilized. Acid is produced from D-cellobiose, D-mannose, melibiose and D-ribose. Acid is not produced from D-melezitose, D-raffinose, sucrose, Dtrehalose, adonitol, myo-inositol or D-sorbitol. Sensitive to cephalothin $(30 \mu \mathrm{g})$, chloramphenicol $(100 \mu \mathrm{g})$ and penicillin $\mathrm{G}(20 \mathrm{U})$ but not to novobiocin $(5 \mu \mathrm{g})$. The predominant respiratory lipoquinone is Q-8. The major fatty acid is $\mathrm{C}_{18: 1} \omega 9 c$. The DNA G $+\mathrm{C}$ content is $43 \cdot 2 \mathrm{~mol} \%$ (HPLC). Other characteristics are shown in Table 1.

The type strain, SW $-210^{\mathrm{T}} \quad\left(=\mathrm{KCTC} \quad 12254^{\mathrm{T}}=\mathrm{DSM}\right.$ $\left.16329^{\mathrm{T}}\right)$, was isolated from sea water of the South Sea in Korea.

\section{Description of Psychrobacter namhaensis sp. nov.}

Psychrobacter namhaensis (nam.ha.en'sis. N.L. masc. adj. namhaensis of Namhae, the Korean name for the South Sea in Korea, where the organism was isolated).

Cells are cocci or short rods $(1 \cdot 0-1 \cdot 2 \times 1 \cdot 4-2 \cdot 5 \mu \mathrm{m})$. On MA, colonies are smooth, glistening, raised, circular to slightly irregular, cream in colour and $1.5-2.5 \mathrm{~mm}$ in diameter after incubation for 3 days at $30^{\circ} \mathrm{C}$. Growth occurs at 4 and $37^{\circ} \mathrm{C}$ but not at $38^{\circ} \mathrm{C}$. Optimal pH for growth is $6.5-7 \cdot 5$; growth occurs at $\mathrm{pH} 5.0$ but not at $\mathrm{pH} 4 \cdot 5$. Growth occurs in the presence of $0-13 \%(\mathrm{w} / \mathrm{v})$ $\mathrm{NaCl}$, with an optimum of $2-3 \%$ (w/v). Yeast extract, biotin, $p$-aminobenzoic acid, thiamine hydrochloride and vitamin $B_{12}$ are not required for growth. Tyrosine is hydrolysed, but hypoxanthine is not. Indole and $\mathrm{H}_{2} \mathrm{~S}$ are not produced. In assays with the API ZYM system, lipase (C8) and leucine arylamidase are present, but trypsin, $\alpha$-chymotrypsin, $\alpha$-galactosidase, $\beta$-galactosidase, $\beta$ glucuronidase, $\alpha$-glucosidase, $\beta$-glucosidase, $N$-acetyl- $\beta$ glucosaminidase, $\alpha$-mannosidase and $\alpha$-fucosidase are absent. Benzoate is utilized. L-Arabinose, D-cellobiose, D-fructose, D-galactose, lactose, maltose, D-mannose, sucrose, D-trehalose, D-xylose, formate and L-glutamate are not utilized. Acid is produced from D-cellobiose,
D-mannose, melibiose and D-ribose. Acid is not produced from D-melezitose, D-raffinose, sucrose, D-trehalose, adonitol, myo-inositol or D-sorbitol. Sensitive to cephalothin $(30 \mu \mathrm{g})$ and chloramphenicol $(100 \mu \mathrm{g})$ but not to novobiocin $(5 \mu \mathrm{g})$ or penicillin $\mathrm{G}(20 \mathrm{U})$. The predominant respiratory lipoquinone is $\mathrm{Q}-8$. The major fatty acid is $\mathrm{C}_{18: 1} \omega 9 \mathrm{c}$. The DNA G $+\mathrm{C}$ content is $45 \cdot 3 \mathrm{~mol} \%$ (HPLC). Other characteristics are shown in Table 1.

The type strain, SW $-242^{\mathrm{T}}\left(=\right.$ KCTC $\left.12255^{\mathrm{T}}=\mathrm{DSM} 16330^{\mathrm{T}}\right)$, was isolated from sea water of the South Sea in Korea.

\section{Acknowledgements}

This work was supported by the 21C Frontier Program of Microbial Genomics and Applications (grant MG02-0401-001-1-0-0) from the Ministry of Science and Technology (MOST) of the Republic of Korea.

\section{References}

Baumann, L. \& Baumann, P. (1981). The marine Gram-negative eubacteria; genera Photobacterium, Beneckea, Alteromonas, Pseudomonas, and Alcaligenes. In The Prokaryotes. A Handbook on Habitats, Isolation, and Identification of Bacteria, pp. 1302-1330. Edited by M. P. Starr, H. Stolp, H. G. Trüper, A. Balows \& H. G. Schlegel. Berlin: Springer.

Bøvre, K. (1984). Genus II. Moraxella Lwoff 1939, 173 emend. Henriksen and Bøvre 1968, 391 ${ }^{\mathrm{AL}}$. In Bergey's Manual of Systematic Bacteriology, vol. 1, pp. 296-303. Edited by N. R. Krieg \& J. G. Holt. Baltimore: Williams \& Wilkins.

Bowman, J. P., Cavanagh, J., Austin, J. J. \& Sanderson, K. (1996). Novel Psychrobacter species from Antarctic ornithogenic soils. Int $J$ Syst Bacteriol 46, 841-848.

Bowman, J. P., Nichols, D. S. \& McMeekin, T. A. (1997). Psychrobacter glacincola sp. nov., a halotolerant, psychrophilic bacterium isolated from Antarctic sea ice. Syst Appl Microbiol 20, 209-215.

Bozal, N., Montes, J., Tudela, E. \& Guinea, J. (2003). Characterization of several Psychrobacter strains isolated from Antarctic environments and description of Psychrobacter luti sp. nov. and Psychrobacter fozii sp. nov. Int J Syst Evol Microbiol 53, 1093-1100.

Bruns, A., Rohde, M. \& Berthe-Corti, L. (2001). Muricauda ruestringensis gen. nov., sp. nov., a facultatively anaerobic, appendaged bacterium from German North Sea intertidal sediment. Int J Syst Evol Microbiol 51, 1997-2006.

Cohen-Bazire, G., Sistrom, W. R. \& Stanier, R. Y. (1957). Kinetic studies of pigment synthesis by nonsulfur purple bacteria. J Cell Comp Physiol 49, 25-68.

Cowan, S. T. \& Steel, K. J. (1965). Manual for the Identification of Medical Bacteria. London: Cambridge University Press.

Denner, E. B. M., Mark, B., Busse, H.-J., Turkiewicz, M. \& Lubitz, W. (2001). Psychrobacter proteolyticus sp. nov., a psychrotrophic, halotolerant bacterium isolated from the Antarctic krill Euphausia superba Dana, excreting a cold-adapted metalloprotease. Syst Appl Microbiol 24, 44-53.

Ezaki, T., Hashimoto, Y. \& Yabuuchi, E. (1989). Fluorometric deoxyribonucleic acid-deoxyribonucleic acid hybridization in microdilution wells as an alternative to membrane filter hybridization in which radioisotopes are used to determine genetic relatedness among bacterial strains. Int J Syst Bacteriol 39, 224-229. 
Juni, E. \& Heym, G. A. (1986). Psychrobacter immobilis gen. nov., sp. nov.: genospecies composed of gram-negative, aerobic, oxidasepositive coccobacilli. Int J Syst Bacteriol 36, 388-391.

Kämpfer, P., Albrecht, A., Buczolits, S. \& Busse, H.-J. (2002). Psychrobacter faecalis sp. nov., a new species from a bioaerosol originating from pigeon faeces. Syst Appl Microbiol 25, 31-36.

Kodjo, A., Tønjum, T., Richard, Y. \& Bøvre, K. (1995). Moraxella caprae sp. nov., a new member of the classical moraxellae with very close affinity to Moraxella bovis. Int J Syst Bacteriol 45, 467-471.

Kodjo, A., Richard, Y. \& Tonjum, T. (1997). Moraxella boevrei sp. nov., a new Moraxella species found in goats. Int J Syst Bacteriol 47, 115-121.

Komagata, K. \& Suzuki, K. (1987). Lipids and cell-wall analysis in bacterial systematics. Methods Microbiol 19, 161-203.

Lanyi, B. (1987). Classical and rapid identification methods for medically important bacteria. Methods Microbiol 19, 1-67.

Leifson, E. (1963). Determination of carbohydrate metabolism of marine bacteria. J Bacteriol 85, 1183-1184.

Maruyama, A., Honda, D., Yamamoto, H., Kitamura, K. \& Higashihara, T. (2000). Phylogenetic analysis of psychrophilic bacteria isolated from the Japan Trench, including a description of the deep-sea species Psychrobacter pacificensis sp. nov. Int J Syst Evol Microbiol 50, 835-846.

Romanenko, L. A., Schumann, P., Rohde, M., Lysenko, A. M., Mikhailov, V. V. \& Stackebrandt, E. (2002). Psychrobacter submarinus sp. nov. and Psychrobacter marincola sp. nov., psychrophilic halophiles from marine environments. Int J Syst Evol Microbiol 52, 1291-1297.

Romanenko, L. A., Lysenko, A. M., Rohde, M., Mikhailov, V. V. \& Stackebrandt, E. (2004). Psychrobacter maritimus sp. nov. and Psychrobacter arenosus sp. nov., isolated from coastal sea ice and sediments of the Sea of Japan. Int J Syst Evol Microbiol 54, 1741-1745.

Sasser, M. (1990). Identification of Bacteria by Gas Chromatography of Cellular Fatty Acids. Newark, DE: MIDI.

Stackebrandt, E. \& Goebel, B. M. (1994). Taxonomic note: a place for DNA-DNA reassociation and 16S rRNA sequence analysis in the present species definition in bacteriology. Int J Syst Bacteriol 44, 846-849.

Staley, J. T. (1968). Prosthecomicrobium and Ancalomicrobium: new prosthecate freshwater bacteria. J Bacteriol 95, 1921-1942.

Tamaoka, J. \& Komagata, K. (1984). Determination of DNA base composition by reverse-phase high-performance liquid chromatography. FEMS Microbiol Lett 25, 125-128.

Vela, A. I., Collins, M. D., Latre, M. V., Mateos, A., Moreno, M. A., Hutson, R., Domínguez, L. \& Fernández-Garayzábal, J. F. (2003). Psychrobacter pulmonis sp. nov., isolated from the lungs of lambs. Int J Syst Evol Microbiol 53, 415-419.

Wayne, L. G., Brenner, D. J., Colwell, R. R. \& 9 other authors (1987). International Committee on Systematic Bacteriology. Report of the ad hoc committee on reconciliation of approaches to bacterial systematics. Int J Syst Bacteriol 37, 463-464.

Yoon, J.-H., Kim, H., Kim, S.-B., Kim, H.-J., Kim, W. Y., Lee, S. T., Goodfellow, M. \& Park, Y.-H. (1996). Identification of Saccharomonospora strains by the use of genomic DNA fragments and rRNA gene probes. Int J Syst Bacteriol 46, 502-505.

Yoon, J.-H., Lee, S. T. \& Park, Y.-H. (1998). Inter- and intraspecific phylogenetic analysis of the genus Nocardioides and related taxa based on 16S rDNA sequences. Int J Syst Bacteriol 48, 187-194.

Yoon, J.-H., Kang, K. H. \& Park, Y.-H. (2003). Psychrobacter jeotgali sp. nov., isolated from jeotgal, a traditional Korean fermented seafood. Int J Syst Evol Microbiol 53, 449-454.

Yoon, J.-H., Yeo, S.-H., Oh, T.-K. \& Park, Y.-H. (2005). Psychrobacter alimentarius sp. nov., isolated from squid jeotgal, a traditional Korean fermented seafood. Int J Syst Evol Microbiol 55, 171-176.

Yumoto, I., Hirota, K., Sogabe, Y., Nodasaka, Y., Yokota, Y. \& Hoshino, T. (2003). Psychrobacter okhotskensis sp. nov., a lipaseproducing facultative psychrophile isolated from the coast of the Okhotsk Sea. Int J Syst Evol Microbiol 53, 1985-1989.

Yurkov, V., Stackebrandt, E., Holmes, A. \& 7 other authors (1994). Phylogenetic positions of novel aerobic, bacteriochlorophyll a-containing bacteria and description of Roseococcus thiosulfatophilus gen. nov., sp. nov., Erythromicrobium ramosum gen. nov., sp. nov., and Erythrobacter litoralis sp. nov. Int J Syst Bacteriol 44, 427-434. 